https://helda.helsinki.fi

Co-generation of societally impactful knowledge in Change Laboratories

\author{
Sannino, Annalisa
}

2017-02

Sannino , A \& Engeström , Y H M 2017 , ' Co-generation of societally impactful knowledge in

Change Laboratories ' , Management Learning , vol. 48 , no. 1 , pp. 80-96 . https://doi.org/10.1177/13505076166712

http://hdl.handle.net/10138/185251

https://doi.org/10.1177/1350507616671285

submittedVersion

Downloaded from Helda, University of Helsinki institutional repository.

This is an electronic reprint of the original article.

This reprint may differ from the original in pagination and typographic detail.

Please cite the original version. 
Sannino, A. \& Engeström, Y. (2017). Sannino, A. \& Engeström, Y. (2017). Co-generation of societally impactful knowledge in Change Laboratories. Management Learning, 48(1), 80-96.

\title{
CO-GENERATION OF SOCIETALLY IMPACTFUL KNOWLEDGE IN CHANGE LABORATORIES
}

\begin{abstract}
Formative interventions and the specific method of the Change Laboratory (CL) are presented as examples of intervention research that generates actionable and societally impactful knowledge. In contrast with stabilization knowledge that fixates phenomena into static categories, actionable knowledge is understood here as collaborative and generative possibility knowledge intertwined with transformative action. The paper asks what can be learned from the different ways the epistemological principles behind formative interventions are implemented in different CLs. Three CL interventions are analyzed. The analysis is summarized with the help of a grid covering the key characteristics of formative interventions: contradictions, conflicts of motives, double stimulation, zone of proximal development, and germ cells and emerging concepts. Comparison of the three cases shows that understanding the specific historical stage of the development of contradictions in a given organization is of foundational importance. In transformations induced by CLs, contradiction and conflict may be seen as acute push and the future-oriented concept as gradually emerging pull, with the change actions of the local practitioners in the middle. Constructing a germ cell and eventually an expanded concrete concept based on it are the most demanding challenges for CL interventions.
\end{abstract}

Keywords: Formative intervention, Change Laboratory, possibility knowledge, double stimulation, germ cell, transformative agency

\section{INTRODUCTION}

In organizational research, demand for actionable and societally impactful knowledge is growing. Such knowledge is typically sought after by means of involving practitioners and other stakeholders in the research endeavor together with academic researchers (Van de Ven, 2007). While this is certainly a precondition for impactful research, it is curious how often the methodologically more radical stance of intervention research is omitted or marginalized in calls for engaged scholarship. Edmondson's (1996) insightful comparative analysis of three major intervention approaches is 20 years old. One looks in vain for discussions of more recent theoretically and methodologically ambitious approaches in major journals in organization studies. Even the current discussions on performativity (Fleming \& Banerjee, 2015) and constituencies of organizational research (Davis, 2015) remain silent about efforts at developing rigorous methodologies of intervention research. 
In this paper we put forward the methodology of formative interventions and the specific method called the Change Laboratory (CL) as potentially powerful examples of intervention research. The methodology of formative interventions stems from the work of Vygotsky, Ilyenkov, Leont'ev, Davydov and other prominent representatives of cultural-historical activity theory (Sannino, 2011). As this primarily psychological and educational research tradition has been taken up and applied to organizational settings outside Russia, it has gained new momentum. Research using formative interventions focuses on transformations in object-oriented activities ${ }^{1}$ in work organizations and communities (Engeström, Sannino \& Virkkunen, 2014). The object and purpose of these activities is typically, at least latently, at risk or in crisis. Formative interventions aim at generating and implementing new models and instruments for the activity, usually first in bounded pilot units.

The methodology of formative interventions is built on two epistemological principles, namely the principle of double stimulation (Vygotsky, 1997) and the principle of ascending from the abstract to the concrete (Ilyenkov, 1982; Davydov, 1990). These principles are also referred to in several studies of organizational settings (for double stimulation see Haapasaari \& Kerosuo, 2015; Higgins \& Mirza, 2010; Palekis, 2011; for ascending from the abstract to the concrete see Blackler, 2011; Hauge \& Norenes, 2014; Virkkunen \& Ristimäki, 2012). Both principles put the formation of volitional action and transformative agency in the center of the intervention. This type of interventions carry future-oriented visions loaded with initiative and commitment. Such visions materialize in novel concepts and practices that enable collaborative development beyond authoritative organizational constraints.

Societally impactful knowledge is actionable knowledge, that is, knowledge that can be turned into transformative action. We suggest that actionable knowledge is typically possibility knowledge (Engeström, 2007), in other words, knowledge about what might be possible new forms and patterns of objects and phenomena in our lifeworlds and social institutions. The formation of possibility knowledge may be seen as opening up and charting the zone of proximal development of the organization (Engeström, 2015, p. 138).

Possibility knowledge takes the shape of future-oriented perspectival concepts, visions and designs. It may be contrasted with stabilization knowledge that fixates things into static definitions and categories which often turn into stereotypes and prejudices. We argue that formative interventions are sites of collaborative generation of possibility knowledge.

For about 20 years, the methodology of formative interventions has been implemented in practice by means of the CL toolkit (Virkkunen \& Newnham, 2013). CL is used when an activity or a cluster of activities faces an uncertain but necessary transformation riddled with conflicting motives and energized by a possibility of reaching a qualitatively new, emancipated mode of activity. In CLs the practitioners take over the

\footnotetext{
${ }^{1}$ In cultural-historical activity theory the key concept of object refers to the "true motive" (Leont'ev, 1978 , p. 62) of an activity, that is, to what generates intentional engagement and is potentially transformed through it. This engagement is also referred to as object orientation or object-relatedness, i.e., a dialectical relationship through which both those who take part in an activity and the activity itself change (Davydov, Zinchenko, \& Talyzina, 1983).
} 
leading role in designing their future by engaging in joint analyses of their activity, often with the help of a conceptual model of the activity system (Engeström, 2015, p. 63). An activity system is a relatively durable formation that consists of actors working on a shared object, mediated by instruments, division of labor, and rules. Modeling the activity system in interventionist efforts reveals the potential of internal contradictions as drivers of transformation. The very point is to generate the unexpected - learning what is not yet there.

The aim of this article is to elucidate and develop further the methodology of formative interventions. The two questions that drive our inquiry are: What can be learned from the different ways in which the epistemological principles of double stimulation and ascending from the abstract to the concrete are implemented in different CL interventions? What challenges may be identified in the deployment and further development of CLs from the point of view of constructing a viable interventionist research methodology in the service of generating societally impactful possibility knowledge?

In the following, we will first present the two epistemological principles, double stimulation and ascending from the abstract to the concrete. After that, we will describe three CL interventions, one conducted in the surgical operating unit of a university hospital, the second one conducted among the managers of the municipal home care services in a large city, and the third one conducted in an academic library of a major university. We will then put forward and explain the conceptual grid we will use in the analysis of the three interventions. We analyze these interventions as attempts to implement the two epistemological principles. The analysis is presented in five sections following the key characteristics of formative interventions. In the concluding section, we will discuss the findings in the light of our research questions.

\section{THE PRINCIPLE OF DOUBLE STIMULATION}

Double stimulation is a principle of volition and agency which characterizes human beings' ability to transform their circumstances (Sannino 2015b). In double stimulation, the first stimulus is a problematic situation which triggers a paralyzing conflict of motives. In CL participants' discourse, the conflict of motives may be manifested in various ways, ranging from latent dilemmas to aggravated double binds that require urgent collective action (Engeström \& Sannino, 2011).

In trying to cope with the problem, an individual or a collective may employ external artifacts which serve the function of meaningful signs. These signs are second stimuli with the help of which the subjects can gain control of the problematic situation. Vygotsky's examples of double stimulation include the throwing of the dice to make a decision (Vygotsky, 1997) and the tying of a knot to counteract the weaknesses of one's own memory (Vygotsky, 1999).

Conflicts of motives play a key role in double stimulation understood as a principle of agency. Mediating artifacts become agentive when they are utilized as second stimuli for facing conflicting motives. To return to Vygotsky's examples, I throw a dice because I am conflicted between two equally motivating alternatives; I use a string around my 
finger because I am aware of my fallible memory and I know that I cannot fail to remember. In CLs, the conflict of motives is triggered and brought into the open by presenting to the participants as first stimuli evidence and examples of recurring problems and disturbances in their activity, often in the form of videotaped critical situations and encounters. The triangular model of an activity system typically serves as second stimulus. This initial second stimulus is often only a transitory device, to be replaced by an artifact the participants find or construct for themselves.

Based on Vygotsky's work, Sannino (2015b) has put forward an elaborate model of the steps of double stimulation. The model has been tested experimentally in arrangements duplicating Vygotsky's description of the double stimulation waiting experiment. Subjects were left in a room expecting to participate in an experiment; as nothing happened, a paralyzing conflict of motives emerged and the subjects had to make sense of the situation (Sannino \& Laitinen, 2015; Sannino, 2015a). The model has also been applied outside the laboratory, in an analysis of critical work encounters (Engeström, Kajamaa \& Nummijoki, 2015) and in an analysis of a CL intervention conducted in a large logistics company (Haapasaari \& Kerosuo, 2015).

\section{THE PRINCIPLE OF ASCENDING FROM THE ABSTRACT TO THE CONCRETE}

The principle of ascending from the abstract to the concrete is the foundational method of dialectical thinking. In activity theory, Davydov (1990), inspired by Ilyenkov (1982), turned this principle into an interventionist method for changing practices of school instruction.

All thinking and learning is abstracting meaning from some initial sensory-concrete diffuse entity, a whole. The learner abstracts from the whole a particular aspect and attributes a meaning to it. There are two types of abstractions: empirical and theoretical. Empirical abstraction is a classification of superficial features of phenomena. Theoretical abstraction refers to the identification of the genetic origins of phenomena that may externally not be alike at all. While observation and categorization are actions at the root of empirical abstraction, practical transformation, change, and experimentation are actions at the root of theoretical abstraction. A theoretical abstraction is based on the identification and modeling of a functional relationship that explains the simple principle behind a complex whole "in a pure, independent, uncovered form" (Vygotsky, 1997, p. 53). Such an abstraction is also called a germ cell. Theoretical abstraction allows one to generate and project complex, theoretically mastered concrete manifestations and developmental forms of the reality under scrutiny. The germ cell is a vehicle for ascending to the concrete. Vygotsky (1997) uses the initial simple drawings of a steam engine as an example. These drawings express the elementary functional germ cell of the principle later named the Rankine cycle, an idealized thermodynamic cycle of an engine that converts heat into mechanical work. The grasping of the simple germ cell generated a huge variety of machinery and means of transport which may externally not look alike at all.

A germ cell is internally contradictory, a dynamic unity of opposites. The most wellknown example of a germ cell is commodity in Marx's theory of capitalism (Ilyenkov, 1982). Every commodity is a contradictory unity of use value and exchange value. In 
this theoretical perspective, a fully developed concept is the product of ascending from the abstract to the concrete. Such a concept connects specific phenomena to their origin and explanatory principle captured in the germ cell. A fully developed concept is expansive in that it opens up rich and diverse possibilities of explanation, practical application, development and creation similarly to the basic principle of steam power in the example above. The theory of expansive learning (Engeström, 2015) is an application of the principle of ascending from the abstract to the concrete.

The principle of ascending from the abstract to the concrete may be connected to the principle of double stimulation in several ways. A conflict of motives and the construction of a second stimulus may be seen as necessary preconditions for ascending from the abstract to the concrete. Usually the second stimulus constructed by subjects as a means for breaking out of a paralyzing conflict of motives is a separate stepping stone toward the modeling of a germ cell, but in some cases the second stimulus may also be a first version of the germ cell. Virkkunen and Schaupp (2011) and Virkkunen and Ristimäki (2012) have sought to bring together the two epistemological principles in their case studies of concept formation and change in organizations. In this article, we will examine CL as deliberate attempts to integrate the principles of double stimulation and ascending from the abstract to the concrete into a coherent intervention methodology.

\section{THREE CL INTERVENTIONS}

In the mid-1990s, researchers in the CRADLE ${ }^{2}$ at University of Helsinki developed an intervention toolkit under the generic name of Change Laboratory. Variations of this toolkit have been used in a large number of intervention studies in settings ranging from post offices and factories to schools, hospitals and newsrooms. CL is typically conducted in an activity system that is facing a major transformation. This is often a relatively independent pilot unit in a large organization. Working practitioners and managers of the unit, together with a small group of interventionist-researchers, conduct six to ten successive CL sessions, with follow-up sessions after some months.

The basic idea behind a CL intervention is that organizations, understood as activity systems, develop and learn through cycles of qualitative transformation. A CL

intervention that follows the logic of ascending from the abstract to the concrete can help the cycle to become expansive. In an expansive cycle, the object of the activity is radically widened, opening up a new horizon of possibilities. For a CL intervention to be effective, it needs to trace the historically accumulated contradictions and build on the energy they engender in the activity system. Historicity and historical analysis, understood as movement between the past, the present and the future, run as a red thread through a CL intervention.

A CL is built on historical and ethnographic data from the activity setting in which it is conducted. Critical incidents, troubles and problems in the work practice are recorded and brought into CL sessions to serve as potential first stimuli. This "mirror data" is

\footnotetext{
${ }^{2}$ Center for Research on Activity, Development and Learning
} 
used to stimulate involvement, analysis and collaborative design efforts among the participants. In the analysis and design, the participants are asked to move between the past, the present, and the future. This means that historical origins of the current problems are dug up and modeled, and the ideas toward a future concept are played with in anticipatory simulations. Two intermediate outcomes of the collective analysis and design in CL are respectively a model conveying the contradictions at play in the current activity and a four-field representation of the zone of proximal development. The laboratory sessions themselves are videotaped for analysis and used as stimuli for reflection.

The first case analyzed in this article is a CL conducted in the Central Surgery Unit of the University Hospital of the city of Oulu in northern Finland in the fall of 2006. The unit was in a near-crisis situation, with long waiting times and queues and negative publicity. Our task was to conduct a collective process in which the problems would be diagnosed and a sustainable solution would be sought. $\mathrm{We}^{3}$ conducted six two-hour CL sessions the participants of which were selected to represent the practitioners working in the unit, from the managing director to surgeons, anesthesiologists, nurses, and representatives of other staff.

Our second case is a CL conducted with the managers of the municipal home care services for the elderly in the city of Helsinki in 2008 and 2009. The home care services had grown rapidly in the past decade and there was increasing criticism that the service did not meet the needs of old people living at home and suffering from chronic illnesses. The task of the intervention was to work out a new, future-oriented concept for home care. The CL consisted of eight sessions, attended by the top manager, six area managers, two or three expert members of the management group, and a personnel representative.

Our third case is a CL conducted in the city center campus library of University of Helsinki in the fall of 2010. The library had just been formed by merging a number of smaller department libraries and it was going to move to a new building constructed for it. This offered an opportunity for the library staff to reconceptualize their activity, especially with regard to their key clients, the researchers. The intervention consisted of eight CL sessions. The sessions were attended by the entire library staff, including the director. Selected sessions were also attended by members of four pilot research groups representing the clients of the library.

\section{THE ANALYTICAL GRID}

Figure 1 represents the grid we constructed for the analysis of the three CLs. The horizontal rows of the grid represent the three CL interventions. The vertical columns represent key characteristics of formative interventions.

The first column contradiction refers to the main contradiction or contradictions identified in the activity system in the course of the CL intervention. The contradictions

\footnotetext{
3 With regard to the interventions, the pronoun "we" stands for the research collective of CRADLE and for the specific research groups responsible for each intervention.
} 
are typically first tentatively identified by the interventionists as a working hypothesis based on their initial historical and ethnographic groundwork. In the CL sessions, the participants work out their own interpretation of the contradictions, which often deviates from the initial version of the interventionists. Finally the interventionistresearchers may work out a further interpretation of the contradictions as they analyze the CL data after the intervention is completed.

The column conflict of motives refers to the conflict as it was articulated by the participants. A conflict of motives is a clash experienced by an individual between opposite aspirations or tendencies which occur in situations involving uncertainty and requiring the courage of deliberate choice. While individual participants experience different versions of a conflict of motives, in a working community the members' workrelated conflicts of motives have shared roots in the contradictions of the activity system.

\begin{tabular}{|c|c|c|c|c|c|}
\hline & CONTRADICTION & $\begin{array}{l}\text { CONFLICT } \\
\text { OF MOTIVES }\end{array}$ & $\begin{array}{l}\text { FIRST AND } \\
\text { SECOND STIMULI }\end{array}$ & $\begin{array}{l}\text { ZONE OF PROXIMAL } \\
\text { DEVELOPMENT }\end{array}$ & $\begin{array}{l}\text { GERM CELL AND } \\
\text { EMERGING CONCEPT }\end{array}$ \\
\hline $\begin{array}{l}\text { SURGICAL } \\
\text { UNIT OF OULU } \\
\text { UNIVERSITY } \\
\text { HOSPITAL }\end{array}$ & & & & & \\
\hline $\begin{array}{l}\text { HOME CARE } \\
\text { MANAGERS } \\
\text { OF THE CITY OF } \\
\text { HELSINKI }\end{array}$ & & & & & \\
\hline $\begin{array}{l}\text { HELSINKI } \\
\text { UNIVERSITY } \\
\text { CITY CENTER } \\
\text { CAMPUS } \\
\text { LIBRARY }\end{array}$ & & & & & \\
\hline
\end{tabular}

Figure 1. Grid for comparative analysis of three CLs

The column first and second stimuli refers firstly to the main problems or disturbances presented to the CL participants ( $1^{\text {st }}$ stimuli). Secondly the column refers to the key artifact actually adopted by the participants as a device for designing their future activity and for taking practical change actions toward that future ( $2^{\text {nd }}$ stimulus).

The column zone of proximal development refers to the way in which the alternative directions of development of the activity were depicted and discussed in the CL. In this phase of the intervention the participants' analysis of the current activity and its history shifts toward the identification of possible future directions to transform the activity. During the CL sessions the participants often represent the zone as a four-field defined by two central dimensions of development salient in the given activity. Examples of such representations are given in Figures 5 and 6 below. 
Finally, the column germ cell and emerging concept refers firstly to articulations of the participants' attempts to construct an initial germ cell idea for the future of their activity. Secondly the column refers to the generalized concrete concept possibly emerging as an outcome of the intervention.

Although contradictions are a necessary precondition for a formative intervention and a concrete concept may be an outcome of it, the five columns in Figure 1 are not presented in a temporal order that would mechanically correspond to their appearance in a CL intervention. In reality, the components of the grid are dynamically intertwined in the intervention process. For example, the zone of proximal development is often but not always - worked out before the second stimulus is crystallized. Similarly, anticipations of a germ cell may sometimes appear very early in the intervention process.

We will now analyze and compare the three CL interventions, starting with the first column of the grid in Figure 1.

\section{CONTRADICTIONS}

In CLs, contradictions are typically identified and depicted with the help of the model of an activity system. Contradictions are worked out in several iterative cycles of analysis. Figure 2 represents an outcome of analysis conducted by the interventionistresearchers after the completion of the CL in the surgical unit. In contrast, Figure 3 is a depiction of contradictions as it was presented to the participants of the library CL.

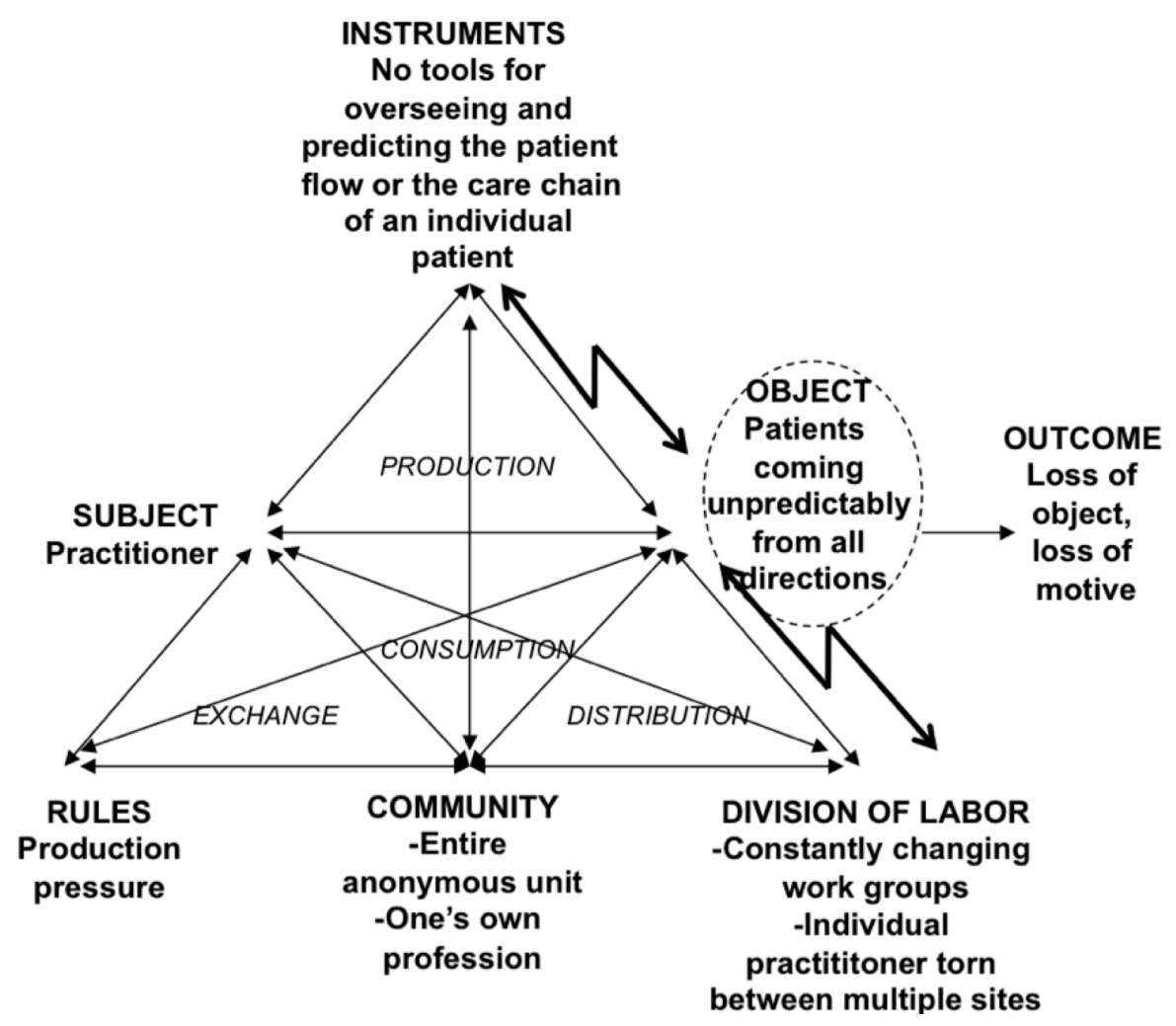

Figure 2. Contradictions in the activity system of the surgery unit (Engeström, 2011, p. 623) 


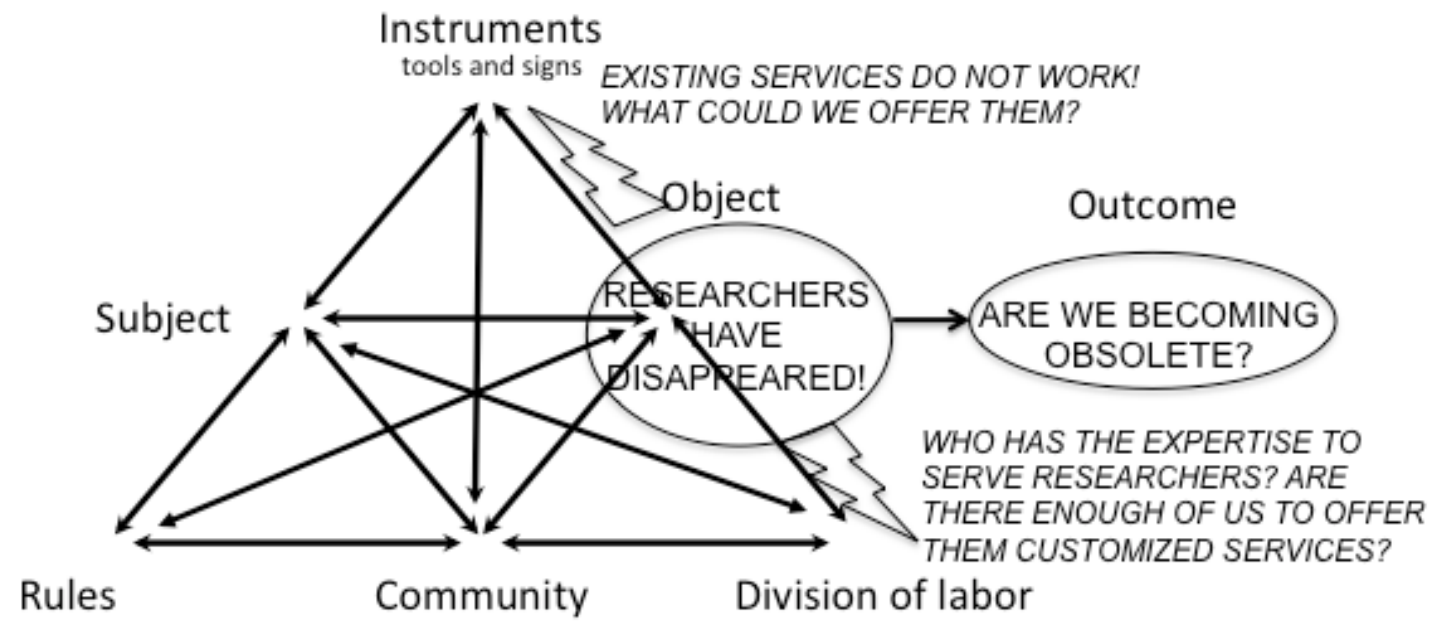

Figure 3. Contradictions in the activity system of the library

Whereas the model in Figure 2 aims at a systematic coverage of all the components of the activity system, the model in Figure 3 is reduced to the essential issue at hand: What is threatening our activity? Also the formulation of the contradictions is done in terms that are close to the conflicts of motives expressed by the participants, typically in the form of burning questions rather than cool statements. Despite these differences, the two sets of contradictions are remarkably similar. In both cases, the meaninggiving object of the activity seemed to be vanishing. In the surgical unit, the patients were becoming anonymous output units or numbers; in the library, researchers, the key clients, were increasingly rarely coming to the library. The loss of the meaningful object generated a contradiction with the persistent standard instruments and division of labor in both organizations.

In the case of the home care managers, the contradictions were from the very beginning identified between the objects of two interconnected activity systems, that of the home care worker and that of the client. The former consisted of standardized routine tasks of maintaining the basic vital functions of the client (nutrition, hygiene, medication) whereas the latter consisted of major challenges and threats to the patient's quality of life (physical mobility, loneliness, memory loss). The gap and tension between these two intertwined objects generated contradictions between the home care professionals' problematic object on the one hand and their standard instruments and division of labor on the other hand. An early version of this analysis was developed and used in the CL sessions (Figure 4; Nummijoki \& Engeström, 2010, p. 51); a more elaborate version was worked out by researcher-interventionists after the completion of the intervention (Engeström \& Sannino, 2011, p. 383). 


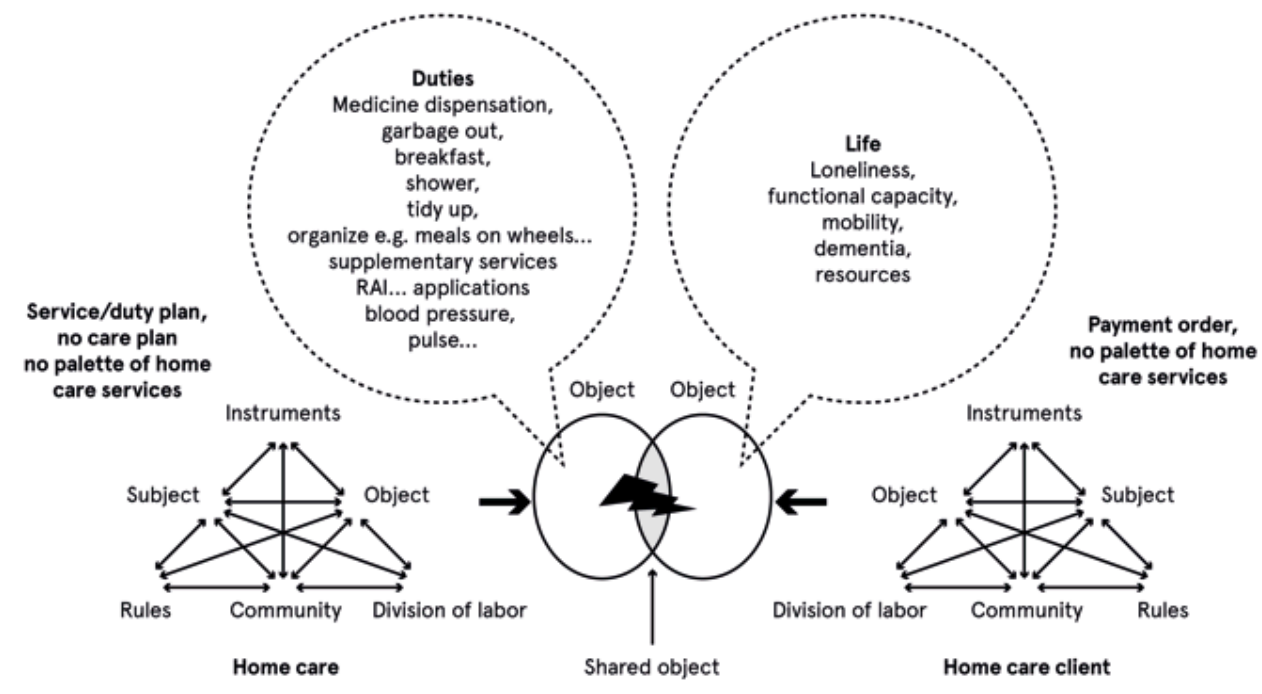

Figure 4. Contradiction in the activity systems of home care (Nummijoki \& Engeström, 2010, p. 51)

\section{CONFLICT OF MOTIVES}

In the surgical unit, the contradictions of the activity system had reached a near-crisis point, with high turnover of staff and excessive numbers of sick leaves, resulting in long waiting times for patients and closures of operating theaters.

\section{EXCERPT 1: CL SESSION 1, SURGICAL UNIT}

048 Researcher 1: (...) is it some kind of a problem, that they have to stay closed, the operating theatres?

049 Anesthesiologist, operation manager: It's a problem in the sense that there are patients in the waiting list who need the operations, and there is a lot of pressure on the other side that they must get treated. This can be seen in the public. So you are between a rock and a hard place all the time. Which gives you the feeling that here we are constantly failing, even though we work harder than ever, we are bad all the same because we cannot get the waiting list to move.

The conflict here was between the motive of protecting staff against getting sick or quitting by keeping the work pressure within tolerable limits and the motive of treating patients in a timely and efficient manner as competent professionals.

\section{EXCERPT 2: CL SESSION 1, SURGICAL UNIT}

113 Senior anesthesiologist: [...] Nobody ever thanks you, the work remains unfinished, you leave, and everything is unfinished, your shift ends and you leave; you never see the reward for the hard work.

The Senior anesthesiologist's comment revealed another aspect of the same basic conflict of motives, namely that between the motive of doing challenging professional 
work and the motive of quitting an unrewarding job in which the work constantly remains "unfinished." The closures of operating theatres epitomized the conflict of motives.

\section{EXCERPT 3: CL SESSION 1, SURGICAL UNIT}

161 Researcher 1: How do the surgeons take it that the theatres are closed?

162 Surgeon 3: It is a red flag.

163 Senior anesthesiologist: It is really bad...

164 Surgeon 3: It is all the bad there can be on the earth.

165 Senior anesthesiologist: It doesn't make sense to educate people to work and then we don't let them work, and there are sick patients as much as anyone can count and then they don't get treated, so it is a completely idiotic system.

Expressions such as "between a rock and a hard place," "we are bad," "red flag," and "idiotic system" signify a strongly experienced conflict of motives. These expressions typically operated with the plural personal pronoun "we" rather than the singular "I," indicating that the conflict of motives was already seen largely in systemic and collective terms that resemble the notion of double bind (Engeström \& Sannino, 2011; Kerosuo, 2011). The conflict of motives was so aggravated that it triggered collective resolution efforts already in the first session of the intervention.

In the home care CL, the conflict of motives was less vividly available at the beginning of the intervention. The strongest expression of a conflict of motives was articulated by a home care manager in the second CL session. Here the conflict emerged between the home care manager's motive of giving adequate services to a needy elderly patient and her motive of acting as a necessary gatekeeper to monitor and restrict the use of limited resources.

\section{EXCERPT 3: CL SESSION 2, HOME CARE}

092 Home care manager 5: As I am myself competent in the substance [of nursing], having been there in the field, I have a terrible agony, about having to be a sort of a policeman and gatekeeper: "no, we cannot," "no, we cannot," "no, we cannot," "unfortunately this will be terminated," "and this... and this, and this, and this." We cannot provide. I don't know. This client's need is completely absurd, what he would want. And I understand it. That is somehow it. And our workers are in panic because they cannot respond to the need. And they have to say "no, we cannot" all the time, and they feel awfully bad about it. They want me to come and say that "no, we cannot," so that they get someone to take the load off their shoulders, that they cannot meet the need.

This excerpt exemplifies critical conflicts expressed in the form of a personal, emotionally charged narrative. Home care manager 5 told her story from the first person "I" perspective, pouring out her distress with formulations such as "I have terrible agony" and using multiple repetitions of the key expression "no, we cannot."

In the university library CL, conflicts of motives were difficult to trace. The participants preferred to talk in calm and detached ways about their work activity and organization. Conflicts popped up primarily as short digressions from the mainly smooth process.

\section{EXCERPT 4: CL SESSION 1, LIBRARY}

131 Librarian 4 [videotaped interview shown to the participants]: In my opinion it is part of a researcher's job to know one's own field of publications, it is kind of included in your competence. I cannot be an expert. We have for example speech sciences, which includes phonetics and logopedics, then psychology, which includes cognitive science. And these now are 
in a way included in my field. Plus then we have three or four similar disciplines and subjects within behavioral sciences alone. So imagine having one person who would be an expert in logopedics, phonetics, speech communication, that is also communication, and then in psychology and cognitive science. So OK, "here I have for you a good publishing forum in cognitive neuroscience, so go ahead and publish there!" [...] No, I cannot muster that! I surely cannot offer that.

Excerpt 4 illustrates a conflict between the motive of being a generalist librarian and the motive of being a competent substance expert in a given domain of science. The conflict was expressed with the characteristic linguistic markers of repeated negatives ("I cannot"; "No, I cannot!"). This conflict is directly related to the contradiction between the emerging object of researchers' new needs in the globally networked world of digital publishing and the traditional division of labor within the academic library. Here the alternatives and opposing forces were, however, less clearcut than in the surgical unit and in the home care. Both the researchers' new needs and the available arrangements of division of labor were relatively poorly charted and minimally debated when we started the CL.

In sum, the conflicts of motives in the three CLs were all connected to the hypothesized contradictions. However, the intensity and degree of aggravation differed between the three interventions, being the most aggravated in the surgical unit and the least aggravated in the library. Correspondingly, in the surgical unit the conflict of motives was primarily expressed as a collective double bind, whereas it was primarily expressed as personal critical conflict in the home care and in the library.

\section{FIRST AND SECOND STIMULI}

In the first session of the CL of the surgical unit, the researcher-interventionists offered a series of videotaped interview clips as potential first stimuli. The very first clips on the closures of operating theatres in fact functioned as powerful first stimulus that brought the conflict of motives to the surface, as shown above in excerpts 1 to 3 .

In the surgical unit, the second stimulus was constructed by the participants, starting already in the first session in which a surgeon brought up the idea of dividing the unit into smaller, relatively independent sub-units. The idea evoked intense discussion-and was endorsed by the participants who began to construct a detailed new organizational structure based on it. The construction of the new organizational structure continued practically through all the six sessions, resulting in a detailed written plan which included a new organization chart for the unit.

In the first session of the home care managers' CL, the researcher-interventionists showed clips of videotaped interviews with two frontline home care workers. In the clips, the workers talked about never having enough time and feeling insufficient in the face of the patients' needs. This first stimulus evoked an intense discussion which eventually led to articulations of the conflict of motives among the participating home care managers. The discussion was focused on troubles and tensions in home care but it did not generate immediate solution efforts. 
In the home care CL, the researcher-interventionists proposed from the beginning that the participants construct a service palette that would for the first time present in understandable form all the services available for the patients. The idea of the service palette became a second stimulus, gradually constructed by the participants as an evolving material artifact, much in the same way as the document presenting the new organizational structure was constructed by the participants of the surgical unit's CL, only with less intensity and commitment.

Also in the library CL, videotaped interview clips were used as potential first stimuli. As shown in excerpt 4 above, the problem of discipline-specific expertise triggered a conflict of motives. The researcher-interventionists suggested knotworking as a preliminary characterization of the new type of work needed in the library: "The notion of knot refers to rapidly pulsating, distributed and partially improvised orchestration of collaborative performance between otherwise loosely connected actors and activity systems" (Engeström, Engeström \& Vähäaho, 1999, p. 346). In knotworking, services would be co-constructed and continuously reconfigured in flexibly changing collaborative formations or partnerships between librarians and research groups. In recent discussions on the future of libraries, a related concept has been suggested, namely "embedded librarianship" (Kvenild \& Calkins, 2011; Shumaker, 2012).

Key managers and staff members of the library gradually adopted the idea of knotworking as a heuristic starting point for the change effort, and the entire project was named "Knotworking in the Library." Besides a brief introduction to the idea at the beginning of the CL process, the researchers did not attempt to define or fix the contents of the notion. Yet the notion started to take a life of its own in the discussions of the participants as shown in Table 1.

Table 1. Frequency of use of the terms "knot" and "knotworking" in the CL sessions of the library

\begin{tabular}{ll}
\hline Session 1 & 1 \\
Session 2 & 0 \\
Session 3 & 1 \\
Session 4 & 1 \\
Session 5 & 3 \\
Session 6 & 6 \\
Session 7 & 13 \\
Session 8 & 13 \\
\hline
\end{tabular}

The table shows a marked increase in the use of the key notions "knot" and "knotworking," starting in session 5 and culminating in sessions 7 and 8. Perhaps more interestingly, in the early sessions these terms were practically exclusively used to refer to collaboration with external clients, the research groups. But starting in sixth session, the term began to be increasingly used to actually envision the way the librarians wanted to learn to work and interact within the library and across the boundaries of the different university campus libraries. This shift was something the interventionists did not expect or plan. In the last two sessions of the CL, the 
participants constructed a new organization chart to be implemented in order to facilitate knotworking both among staff across campus libraries and between staff and research groups. This new organization chart may be seen as a materialization of the second stimulus.

\section{ZONES OF PROXIMAL DEVELOPMENT}

In the CL of the surgical unit, the new model of the activity, based on smaller sub-units, began to take shape already in the first session. However, from its very inception, the second stimulus (the new organizational model) was inherently ambiguous in that it implied two possible and partly conflicting directions of development. The first one was specialization, the second one was characterized as a new kind of shared responsibility. In a way, specialization and shared responsibility were opposite images of the outcome. Specialization implies focusing on a narrower field, with more depth. The new responsibility envisioned collective focus on a wider field: "to see the whole." The need for such a wider or more holistic perspective was formulated in terms of a single patient's "entire chain of care" and, more broadly, in terms of the overall flow of patients. The detailed model was worked out as an attempt to merge the positive potentials of both specialization and holistic responsibility. However, the zone of proximal development was never constructed in a diagrammatic form, as the participants were eager to push toward an implementable organization model.

In the home care, the zone of proximal development was formulated and discussed in the sessions with the help of diagrams such as Figure 5. The figure depicts a field in which development starts from the historical tradition of institutionalized care for poor old people, opening up possibilities in two directions, namely increased equality and increased choice. The participants discussed the virtues and limitations of the available three directions of development, gathering information on different national models also from their colleagues abroad. They ended up focusing on the upper righthand field which represents a merging of equality and clients' independent decision making, or security and flexibility. They saw the service palette they were designing as a small first step toward that direction. 


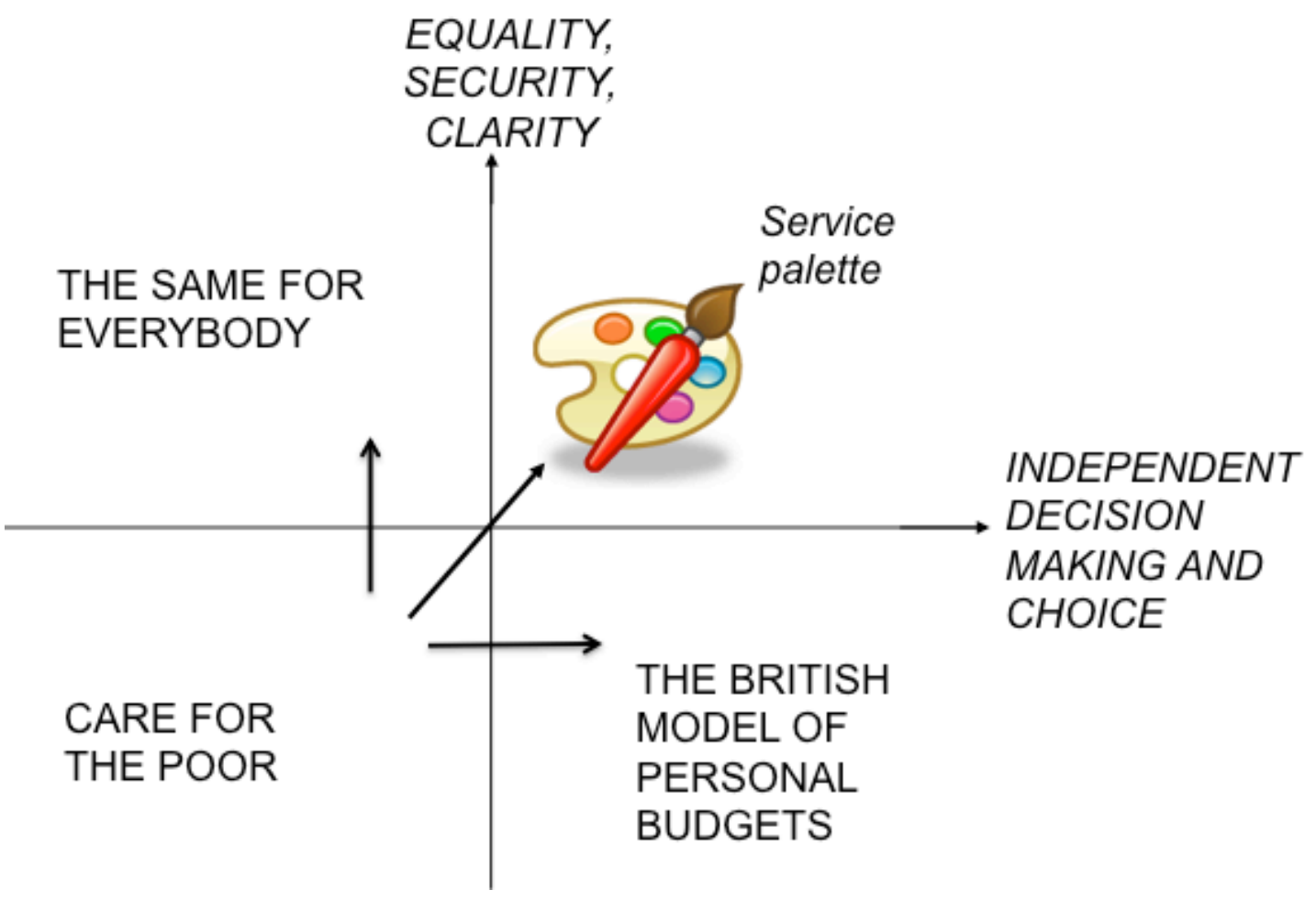

Figure 5. The zone of proximal development in the home care CL

In the library CL, the process of charting the zone of proximal development was quite similar. Figure 6 depicts a field in which there are three available directions of development from a traditional departmental academic library. The participants focused on the direction represented by the upper right-hand corner of Figure 6.

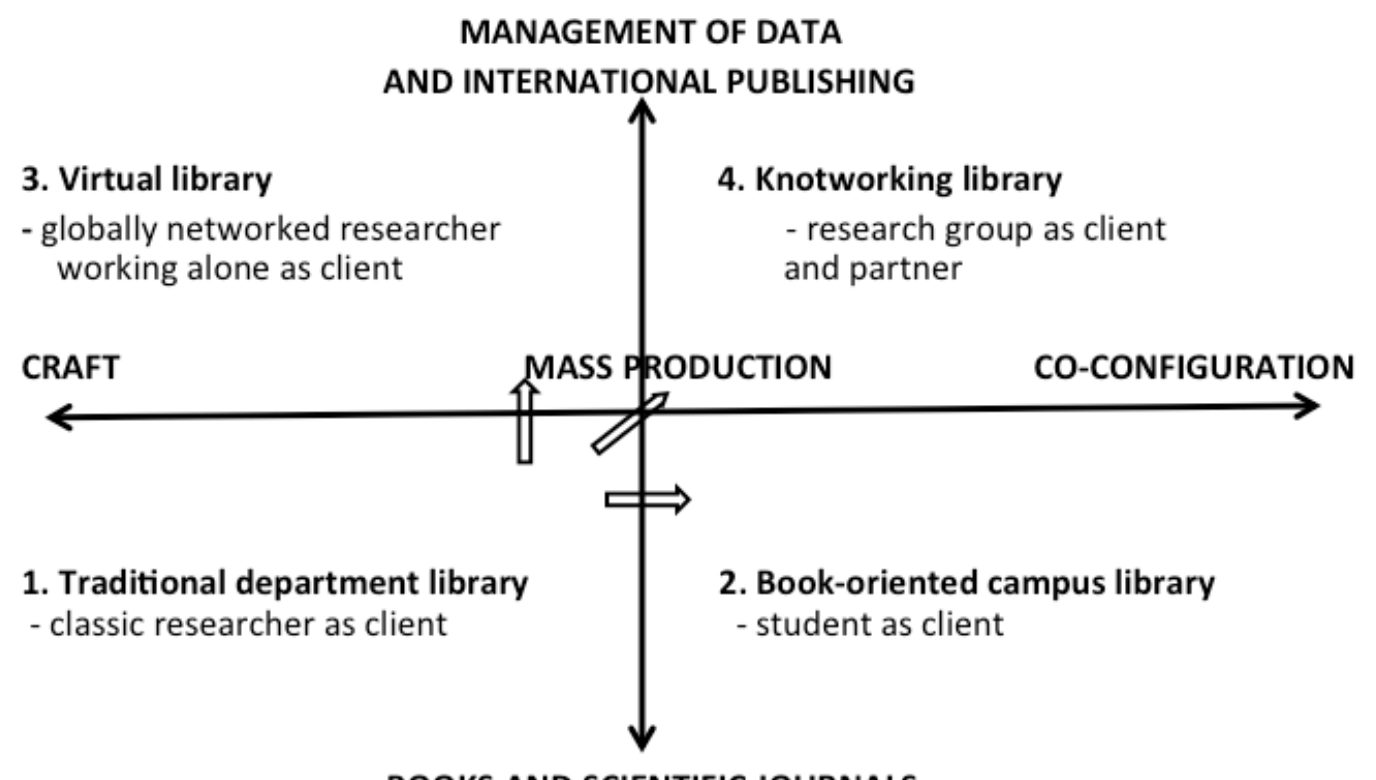

BOOKS AND SCIENTIFIC JOURNALS

Figure 6. The zone of proximal development in the library CL 
Clearly the choice and definition of the dimensions of development are crucial for the meaningful identification of a zone of proximal development. As Figures 5 and 6 show, the construction of the dimensions is based on historical analysis of the evolution of the focal activity system. Just like the contradictions discussed above, depictions of the zone of proximal development are working hypotheses - tools to be worked with, tested and modified. They are of central importance in the building of dynamic possibility knowledge. The fact that the zone of proximal development was not explicitly represented in the surgical unit may have contributed to the relatively weak concept formation in that case.

\section{GERM CELLS AND EMERGING CONCEPTS}

The surgical unit CL generated the notion of responsibility, or holistic care responsibility, which may be regarded as a rudimentary beginning of a germ cell and potential concept. However, although this notion was taken up in the sessions, it remained outside the focus of collective articulation and modeling. The focus was on the design and implementation of a workable organization model as a solution to the pressing contradictions of the activity. In a way, what became more important than why.

In the home care CL, the notion of integration, or integrated home care service, was generated. This notion was frequently explicated by the participants during the intervention and afterwards it has gained currency in the field of home care. However, here too, the germ cell and potential concept were not articulated in a focused way, as the participants' efforts were mainly directed to completing the service palette as a practically useful outcome.

In the library CL, the notion of knot, or knotworking, was established and articulated as a germ cell idea. The library case is the only one in which the second stimulus and the emerging germ cell coincided. In the course of the intervention, the participants increasingly focused on explicating their interpretation of knotworking and the emerging concept of "knotworking in the library" became a powerful future perspective for the library, promoted in collectively authored articles in journals of the library profession (e.g., Engeström \& al., 2012).

Each one of these potential germ cells is still in a rather embryonic state. We are following the implementation and possible expansion of each one of them to push forward and better understand the process.

\section{CONCLUSION}

What can be learned from the different ways in which the epistemological principles of double stimulation and ascending from the abstract to the concrete have been implemented in different CL interventions? The analysis of the three interventions conducted above may be summarized with the help of the grid presented in Figure 2, now filled with our findings (Figure 7). 


\begin{tabular}{|c|c|c|c|c|c|}
\hline & CONTRADICTION & $\begin{array}{l}\text { CONFLICT } \\
\text { OF MOTIVES }\end{array}$ & $\begin{array}{l}\text { FIRST AND } \\
\text { SECOND STIMULI }\end{array}$ & $\begin{array}{l}\text { ZONE OF PROXIMAL } \\
\text { DEVELOPMENT }\end{array}$ & $\begin{array}{l}\text { GERM CELL AND } \\
\text { EMERGING CONCEPT }\end{array}$ \\
\hline $\begin{array}{l}\text { SURGICAL } \\
\text { UNIT OF OULU } \\
\text { UNIVERSITY } \\
\text { HOSPITAL }\end{array}$ & $\begin{array}{l}\text { UNPREDICTABLE } \\
\text { PATIENT FLOW VS. } \\
\text { FRAGMENTED TOOLS } \\
\text { AND DIVISION OF } \\
\text { LABOR }\end{array}$ & $\begin{array}{l}\text { PROTECTING STAFF } \\
\text { AGAINST OVERLOAD } \\
\text { VS. PROVIDING CARE } \\
\text { FOR PATIENTS IN A } \\
\text { TIMELY MANNER }\end{array}$ & 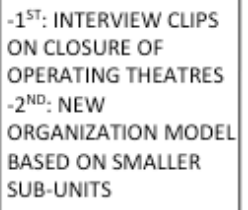 & $\begin{array}{l}\text { THE DIMENSIONS: } \\
\text { (1) WIDER } \\
\text { RESPONSIBILITY } \\
\text { (2) DEEPER } \\
\text { SPECIALIZATION }\end{array}$ & $\begin{array}{l}\text { HOLISTIC } \\
\text { RESPONSIBILITY FOR } \\
\text { PATIENTS }\end{array}$ \\
\hline $\begin{array}{l}\text { HOME CARE } \\
\text { MANAGERS } \\
\text { OF THE CITY OF } \\
\text { HELSINKI }\end{array}$ & $\begin{array}{l}\text { PATIENTS' NEED FOR } \\
\text { INDIVIDUALIZED } \\
\text { HOLISTIC SERVICES } \\
\text { VS. CURRENT } \\
\text { FRAGMENTED } \\
\text { STANDARD } \\
\text { SERVICES }\end{array}$ & $\begin{array}{l}\text { GIVING ADEQUATE } \\
\text { SERVICES THE THE } \\
\text { NEEDY VS. ACTING } \\
\text { AS GATEKEEPER } \\
\text { AND SAVING } \\
\text { RESOURCES }\end{array}$ & 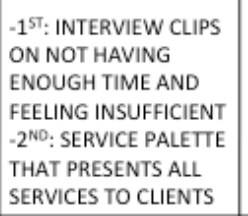 & $\begin{array}{l}\text { THE DIMENSIONS: } \\
\text { (1) INCREASING } \\
\text { EQUALITY AND } \\
\text { SECURITY } \\
\text { (2) INCREASING } \\
\text { CHOICE AND } \\
\text { FLEXIBILITY }\end{array}$ & $\begin{array}{l}\text { INTEGRATION, } \\
\text { INTEGRATED HOME } \\
\text { CARE SERVICE }\end{array}$ \\
\hline $\begin{array}{l}\text { HELSINKI } \\
\text { UNIVERSITY } \\
\text { CENTRAL } \\
\text { CAMPUS } \\
\text { LIBRARY }\end{array}$ & $\begin{array}{l}\text { RESEARCH GROUPS' } \\
\text { NEW INFORMATION, } \\
\text { DATA MANAGEMENT } \\
\text { AND PUBLISHING } \\
\text { NEEDS VS. } \\
\text { TRADITIONAL } \\
\text { LIBRARY SERVICES }\end{array}$ & $\begin{array}{l}\text { BEING A GENERALIST } \\
\text { LIBRARIAN VS. BEING } \\
\text { A SUBSTANCE } \\
\text { EXPERT IN A } \\
\text { DOMAIN OF SCIENCE }\end{array}$ & 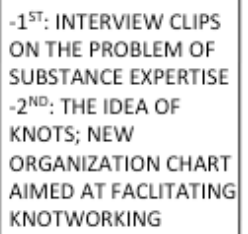 & $\begin{array}{l}\text { THE DIMENSIONS: } \\
\text { (1) FROM CRAFT TO } \\
\text { CO-CONFIGURATION } \\
\text { (2) FROM BOOKS AND } \\
\text { JOURNALS TO DATA } \\
\text { MANAGEMENT AND } \\
\text { GLOBAL ELECTRONIC } \\
\text { PUBLISHING }\end{array}$ & $\begin{array}{l}\text { KNOTS; } \\
\text { KNOTWORKING } \\
\text { AMONG STAFF AND } \\
\text { BETWEEN STAFF AND } \\
\text { RESEARCH GROUPS }\end{array}$ \\
\hline
\end{tabular}

Figure 7. Key findings concerning the three CLs

In all the three interventions, the crucial contradiction was found stemming from the changing object that generates growing tension with the existing instruments and divisions of labor. In the surgical unit and in the library, the object - the key clients and their needs - seemed to be vanishing. In the home care, the object - the needs of sick old people living at home - seemed to be divorced from the administratively defined object of home care workers.

In the surgical unit, the contradiction manifested itself in an aggravated, collectively articulated conflict of motives that led to a speedy and focused redesign effort by the practitioners. The interventionist-researchers were taken by surprise when the participants formulated their second stimulus and began to sketch the germ cell of their future activity already in the first CL session. In the home care and in the library, the conflict of motives was less aggravated and was expressed in individual accounts. Thus also the redesign efforts in these organizations were more cautious and tentative. Among the home care managers, the germ cell notion of "integration" emerged late, as a tail of the concrete effort of constructing a service palette. In the library the germ cell notion of "knotworking" took shape gradually, mostly in the last two sessions (Table 1).

These differences between the interventions indicate that the specific historical stage of the development of contradictions in a given organization is of foundational importance for the ways in which a CL may be carried out with impact. This means that the history of the focal activity systems needs to be analyzed before and during the actual intervention in terms of past and ongoing developmental cycles. Such a historical analysis in a formative intervention aims at articulating the currently 
emerging or already pressing contradictions of the activity. It also produces the basis for identifying possible alternative directions for the future, as evidenced in representations of zones of proximal development (Figures 5 and 6). The understanding of one's own history becomes the foundation for assessing change and determining what might be progress.

The aggravated contradiction and conflict of motives led to a focused generation and implementation of a new organization model in the surgical unit. However, the formation of a new concept that could guide the development of the activity in a longer perspective remained weak in this case. Concept formation was strongest in the library, even though the implementation of their organization model was only partial. This indicates that the degree of aggravation of the contradiction and conflict of motives does not mechanically determine the outcome and impact of the intervention. We might think of the contradiction and conflict as acute push and the future-oriented concept as gradually emerging pull, with the change actions of the local practitioners in the middle. In the surgical unit there was strong push and weak pull, whereas in the library there was weak push but relatively strong pull. The home care intervention seems to have had medium push and medium pull.

What challenges may be identified in the deployment and further development of CLs from the point of view of constructing a viable interventionist research methodology in organization studies? Generating a germ cell and eventually an expanded concrete concept based on it are the most demanding challenges for CL interventions. Often we see the first rudiments of a germ cell abstraction emerging, but it is rare to see it fully modeled and developed into a concept. A single CL intervention covering six to ten sessions is in many cases simply too short for this kind of an accomplishment. That is why in current research increasing attention is paid to following longer-term consequences and possible additional rounds of formative interventions in various sites (e.g., Haapasaari \& Kerosuo, 2015).

An important hallmark of a germ cell is its generative potential that stems from its dynamic character as a unity of opposing forces or tendencies. As pointed out above, the notion of responsibility in the surgical unit was such a unity of narrower specialization on the one hand - and broader overview of patients' trajectories on the other hand. The notion of integration in home care was a unity of taking charge of and coordinating previously fragmented services - and delegating various services to partners and subcontractors. The notion of knot in the library was a unity of turning inward to pool and combine the competences of staff in flexible ways - and turning outward to manage partnerships with research groups. Modeling these dynamic relations is a challenge for future interventions.

The grid of Figure 7 can itself be read as a depiction of movement, from the tentative identification of contradictions to the use of problematic first stimuli to trigger a conflict of motives, to the construction of second stimuli to break out of the paralyzing conflict, and on to the formulation of a zone of proximal development and a germ cell abstraction that gives specificity and substance to the general developmental direction the participants have committed to. In other words, the grid itself is an overview of the different steps and representational modes in the formation of possibility knowledge. 
Possibility knowledge is a multi-step process of double stimulation and ascending from the abstract to the concrete.

\section{ACKNOWLEDGMENTS}

The writing of this article was supported by an Academy Research Fellowship (No. 292730) granted to Annalisa Sannino by the Academy of Finland, Research Council for Culture and Society. The writing was also supported by a grant (No. 253804) from the Academy of Finland for the project "Concept formation and volition in collaborative work", PI Yrjö Engeström.

\section{REFERENCES}

Blackler, F. (2011). Power, politics, and intervention theory: Lessons from organization studies. Theory \& psychology, 21(5), 724-734.

Davis, G. F. (2015). Editorial essay: What is organizational research for? Administrative Science Quarterly, 60(2), 179-188.

Davydov, V. V. (1990). Types of generalization in instruction: Logical and psychological problems in the structuring of school curricula. Reston, VA: National Council of Teachers of Mathematics.

Davydov, V. V., Zinchenko, V. P., \& Talyzina, N. F. (1983). The problem of activity in the works of A. N. Leont'ev. Soviet Psychology, 21(4), 31-42.

Edmondson, A. (1996). Three faces of Eden: The persistence of competing theories and multiple diagnoses in organizational intervention research. Human Relations, 49(5), 571-595.

Engeström, Y. (2007). From stabilization knowledge to possibility knowledge in organizational learning. Management Learning, 38(3), 271-275.

Engeström, Y. (2015). Learning by expanding: An activity-theoretical approach to developmental research. $2^{\text {nd }}$ edition. Cambridge: Cambridge University Press.

Engeström, Y., Engeström, R. \& Vähäaho, T. (1999). When the center does not hold: The importance of knotworking. In S. Chaiklin, M. Hedegaard \& U. J. Jensen (Eds.), Activity theory and social practice: Cultural-historical approaches. Aarhus: Aarhus University Press.

Engeström, Y., Kaatrakoski, H., Kaiponen, P., Lahikainen, J., Laitinen, A., Myllys, H. \& Sinikara, K. (2012). Knotworking in academic libraries: Two case studies from the University of Helsinki. Liber Quarterly, 21(3/4), 387-405. 
Engeström, Y., Kajamaa, A., \& Nummijoki, J. (2015). Double stimulation in everyday work: Critical encounters between home care workers and their elderly clients. Learning, Culture and Social Interaction, 4, 48-61.

Engeström, Y., Kerosuo, H. \& Kajamaa, A. (2007). Beyond discontinuity: Expansive organizational learning remembered. Management Learning, 38(3), 319-336.

Engeström, Y., Rantavuori, J. \& Kerosuo, H. (2013). Expansive learning in a library: Actions, cycles and deviations from instructional intentions. Vocations and Learning, 6(1), 81-106.

Engeström, Y. \& Sannino, A. (2011). Discursive manifestations of contradictions in organizational change efforts: A methodological framework. Journal of Organizational Change Management, 24(3), 368-387.

Engeström, Y., Sannino, A. \& Virkkunen, J. (2014). On the methodological demands of formative interventions. Mind, Culture, and Activity, 21, 118-128.

Fleming, P., \& Banerjee, S. B. (2015). When performativity fails: Implications for Critical Management Studies. Human Relations, 0018726715599241.

Haapasaari, A., \& Kerosuo, H. (2015). Transformative agency: The challenges of sustainability in a long chain of double stimulation. Learning, Culture and Social Interaction, 4, 37-47.

Hauge, T. E., \& Norenes, S. O. (2014). Collaborative leadership development with ICT: experiences from three exemplary schools. International Journal of Leadership in Education, (ahead-of-print), 1-25.

Higgins, D., \& Mirza, M. (2010). Learning in and through work practices: mediational artefacts as a process of social learning in the knowledge-based small firm. International Journal of Innovation and Learning, 8(2), 189-207.

Ilyenkov, E. V. (1982). The_dialectics of the abstract and the concrete in Marx's Capital. Moscow: Progress.

Kerosuo, H. (2011). Caught between a rock and a hard place: From individually experienced double binds to collaborative change in surgery. Journal of Organizational Change Management, 24(3), 388-399.

Kvenild, C. \& Calkins, K. (Eds.) (2011). Embedded librarians: Moving beyond one-shot instruction. Chicago: Association of College and Research Libraries.

Leont'ev, A. N. (1978). Activity, consciousness, and personality. Englewood Cliffs, NJ: Prentice-Hall.

Nummijoki, J. \& Engeström, Y. (2010). Towards co-configuration in home care of the elderly: Cultivating agency by designing and implementing the mobility agreement. In 
H. Daniels, A. Edwards, Y. Engeström, T. Gallagher, \& S. Ludvigsen (Eds.), Activity theory in practice: Promoting learning across boundaries and agencies. London: Routledge.

Peleckis, K. (2011). Management of the research and technical potential of a higher school: theoretical aspects of improvement. Current Issues of Business and Law, 1, 101109.

Sannino, A. (2011). Activity theory as an activist and interventionist theory. Theory \& Psychology, 21(5), 571-597.

Sannino, A. (2015a). Double Stimulation in the Waiting Experiment with Collectives: Testing a Vygotskian Model of the Emergence of Volitional Action. Integrative Psychological and Behavioral Science, 1-32.

Sannino, A. (2015b). The principle of double stimulation: A path to volitional action. Learning, Culture, and Social Interaction, 6, 1-15.

Sannino, A. \& Laitinen, A. (2015). Double stimulation in the waiting experiment: Testing a Vygotskian model of the emergence of volitional action. Learning, Culture, and Social Interaction, 4, 4-18.

Shumaker, D. (2012). The embedded librarian: Innovative strategies for taking knowledge where it's needed. Medford: Information Today.

Van de Ven, A. H. (2007). Engaged scholarship: A guide for organizational and social research. Oxford: Oxford University Press.

Virkkunen, J. \& Newnham, D. S. (2013). The Change Laboratory: A tool for collaborative development of work and education. Rotterdam: Sense Publishers.

Virkkunen, J. \& Ristimäki, P. (2012). Double stimulation in strategic concept formation: An activity-theoretical analysis of business planning in a small technology firm. Mind, Culture, and Activity, 19(3), 273-286.

Virkkunen, J. \& Schaupp, M. (2011). From change to development: Expanding the concept of intervention. Theory \& Psychology, 21(5), 629-655.

Vygotsky, L. S. (1997). The collected works of L. S. Vygotsky: Vol. 4. The history of the development of higher mental functions. New York: Plenum.

Vygotsky, L. S. (1999). The collected works of L. S. Vygotsky. Vol. 6: Scientific legacy. New York: Plenum. 